\title{
En uvanlig årsak til dyspné
}
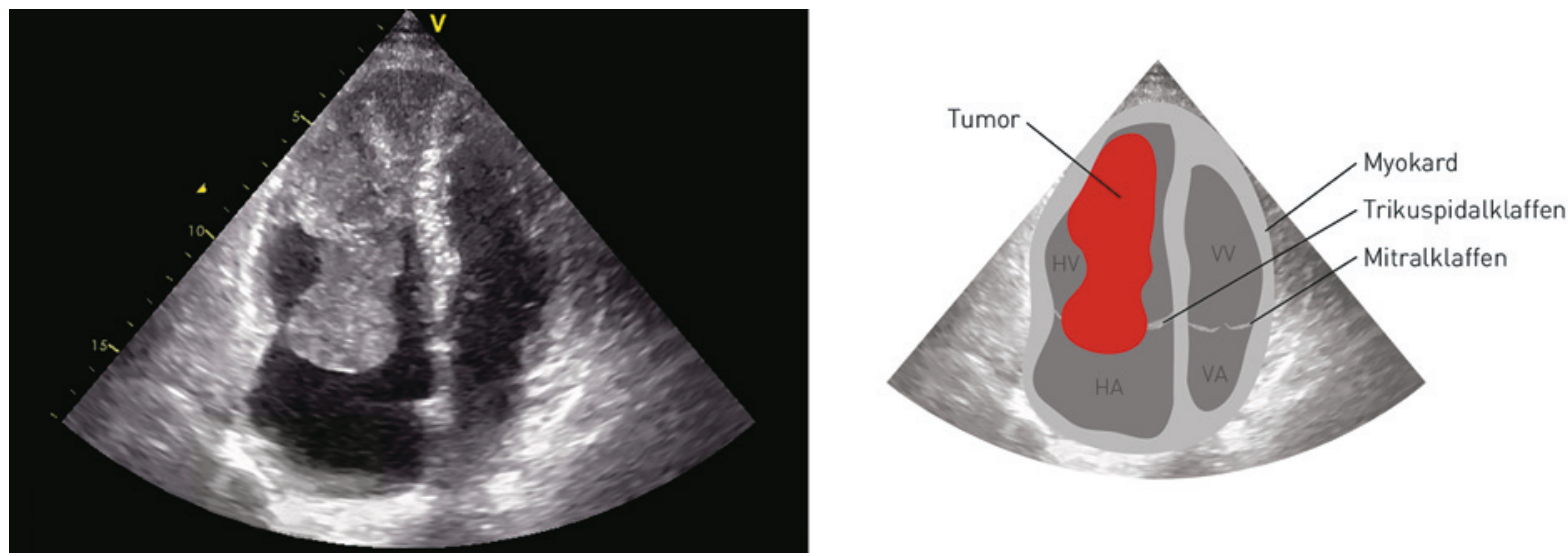

En mann i 50-årene kontaktet onkologisk poliklinikk etter to uker med moderat dyspné og svimmelhet. Ti måneder tidligere hadde han fått diagnostisert kreft $\mathrm{i}$ thyreoidea av blandingstype (30\% høyt differensiert follikulært og papillært karsinom, 70\% lavt differensiert karsinom) med lungemetastaser. Han var operert og hadde fătt postoperativ radiojodbehandling og strålebehandling mot collum.

Pasienten var febril $\left(38,1^{\circ} \mathrm{C}\right)$, og CRPnivået var $52 \mathrm{mg} / 1$. Han hadde lett sinustakykardi (102/min), blodtrykket var 128/90 $\mathrm{mm} \mathrm{Hg}$ og $\mathrm{O}_{2}$-saturasjon i hvile var $100 \%$. Man hørte en svak systolisk bilyd langs venstre sternalrand.

CT thorax viste lungemetastaser, men også en oppfylling i hjertet. Ekkokardiografi (apikalt 4-kammersnitt uten kontrast) (bilde) viste at oppfyllingen fylte ut det meste av høyre ventrikkel og at en større del prolaberte gjennom trikuspidalklaffen. Kontrastforsterket MR av hjertet talte for at oppfyllingen var en tumor, ikke en trombe. Med tilgang via vena jugularis interna ble det tatt biopsi fra septum. Den bekreftet spredning fra lavt differensiert thyreoideakarsinom.

Metastaser til hjertet fra thyreoideakreft er svært sjelden. Hva som er beste behandling, er ikke fastslått. Etter diskusjon i tverrfaglig team avsto man fra operasjon grunnet høy komplikasjonsrisiko og liten sannsynlighet for å oppnå fri reseksjonskant. Lavt differensiert thyreoideakreft er lite sensitiv for strålebehandling og kjemoterapi. Strålebehandling kan gi lokal kontroll, men effek- ten på overlevelse er lite dokumentert. Ved strålebehandling er det vist bedre effekt med totaldose $>30$ Gy (1).

Pasienten fikk strålebehandling $2 \mathrm{~Gy} \times 20$ mot hjertet, uten komplikasjoner.

Ekkokardiografi etter behandlingen viste at tumorstørrelsen var halvert. Pasienten hadde ikke lenger dyspné. Sykdommen progredierte imidlertid med flere metastaser i lunge og skjelett, og pasienten døde etter ett år.

Pasienten og pasientens pårørende har gitt samtykke til at artikkelen blir publisert.

\section{Ragnhild Habberstad}

ragnhild.habberstad@gmail.com

Jarle Karlsen

Kreftklinikken

St. Olavs hospital

\section{Knut Haakon Stensæth}

Klinikk for bildediagnostikk

St. Olavs hospital

og

Institutt for sirkulasjon og bildediagnostikk

Norges teknisk-naturvitenskapelige universitet

\section{Thomas Renhult Skaug}

Klinikk for hjertemedisin

St. Olavs hospital

\section{Brage H. Amundsen}

Klinikk for hjertemedisin

St. Olavs hospital

Ragnhild Habberstad (f. 1984) er lege i spesialisering.

Forfatter har fylt ut ICMJE-skjemaet og oppgir

ingen interessekonflikter.
Jarle Karlsen (f. 1961) er overlege. Forfatter har fylt ut ICMJE-skjemaet og oppgir ingen interessekonflikter.

Knut Haakon Stensæth (f. 1961) er ph.d., overlege og førsteamanuensis II.

Forfatter har fylt ut ICMJE-skjemaet og oppgir ingen interessekonflikter.

Thomas Renhult Skaug (f. 1969) er overlege. Forfatter har fylt ut ICMJE-skjemaet og oppgir ingen interessekonflikter.

Brage H. Amundsen (f. 1976) er ph.d., lege i spesialisering og forsker.

Forfatter har fylt ut ICMJE-skjemaet og oppgir ingen interessekonflikter.

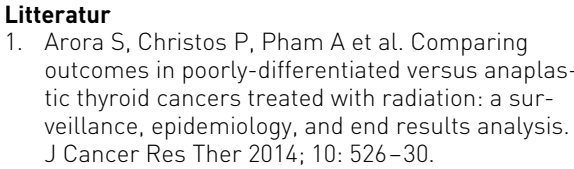

1. Arora S, Christos P. Pham A et al. Comparing outcomes in poorly-differentiated versus anaplastic thyroid cancers treated with radiation: a surveillance, epidemiology, and end results analysis. J Cancer Res Ther 2014; 10: 526-30.

Mottatt 14.5. 2015, første revisjon innsendt 12.9. 2015, godkjent 20.1. 2016. Redaktør: Inge Rasmus Groote.

Video på www.tidsskriftet.no 